\title{
HUMANISM AND THE LAW: TOWARDS AFRICAN RENNAISSANCE
}

\author{
Ikenga K.E. Oraegbunam* \\ http://dx.doi.org/10.4314/og.v9i1.13
}

\section{Abstract}

The role of law in the ordering of human society cannot be over-emphasized. It is by law that offenders are brought to book and punished in view of deterrence and other purposes. It is also in accordance with the law that grievances should be ventilated and injuries suffered by the victims redressed. Law provides a framework of rules that determine the validity of private transactions and then leaves the individual with the option of arranging his private affairs the way he likes within the parameters of the law. Too, the regulation of administrative procedures and exercises, and formation of companies constitute a product of law. It is equally needless to mention that fiscal responsibilities and conferral of social benefits are more easily conducted by means of genuine legislations. All these social functions of law coalesce in the act of developing the human resource. Hence, law and humanism meet in the human person. This meeting presupposes that all forms of legislation and all ideas of humanism, African or western, must have the integral development of man as their target. This paper examines the different shades of humanism in African and Western thoughts and delineates the possible roles of law towards enhancing the growth of the African human capital

Key Words: Humanism, Law, African Renaissance, Development, Jurisprudence 
Oraegbunam: Humanism ans the Law: Towards African Rennaissance

\section{Introduction}

For the purpose of this investigation in relation to African renaissance and development, humanism is meant to be a blanket term covering those streams of thought and action which aim at fostering the full and integral development of man, that is, protecting his dignity, loving and caring for him. This paper talks of a humanism that takes into consideration the holistic dimensions of man: social, psychological, economic, political, cultural, religious, technological, scientific, and artistic.

On the other hand, it is discovered by this paper that presently, the term development has been mis-conceived or conceived partially in terms of material progress. The spiritual, moral and the social aspects are either thrown to the dogs or disregarded. And there is nothing in the analysis of the term development which points only to the positive direction. According to Opafola, "development can be regressive, or stagnant or progressive" "In this paper, however, we understand by the word development only in the progressive sense which aids the progress of the totality of the person which involves, in the words of Iroegbu, the "noema-noetic, psycho-somatic, socio-cultural, individual-collective, rationalemotional, human-divine integrated being"2. Therefore, development here means the human being progressing in these various aspects. Development has to be Integral which means complete, whole, all-round, and holistic. Therefore as used in relation to humanism, integral development refers to human promotion and progress in its entire ramification.

The main thrust of this paper is to critically review the various strands of humanism in western and African thoughts. It will crystallize the basic elements of integral humanism, and settles with the role of law in human development in Africa. Critical and jurisprudential analysis would constitute the research methodology. 


\section{Humanism in Western Thought}

It has often been said that the term humanism is a slippery word that today covers a watershed of opinions, attitudes, outlooks and movements that center on man. Hence, there are varieties of humanism, challenges of humanism, and enigmas of humanism. Various scholars have devoted a wide range of interest on these aspects of humanism. Some aspects are theistic, others atheistic; some are literary and intellectual, others ethical and political. Goicoechea states the distinction between two kinds of humanism: the one signified by the word philanthropy and the other by paideia. He holds that it is along this line that humanism of any kind might be understood.

The varieties of humanism might be understood in relation to these two original kinds. In Greek times, it was from Promethean humanism that philanthropy sprang forth. It was from the humanism of the sophists that Paideia came forth ${ }^{3}$.

It is observed that history of humanism has always maintained this distinction. Roman humanism recognized philanthrophy and paideia.

In Rome the distinction continued. Philanthropy gathered to a greatness around the Stoic recta ratio. All humans are of a family because they are collected by the Heraclitean logos which became right reason ..... At the same time, the Romans were the first to institutionalize paideic humanism. The school curriculum was based on the great books of rhetorical tradition... In Rome the two kinds of humanism were distinct and confrontational...Yet Cicero argued that because of the paideic learning the Stoic philanthropy could work ${ }^{4}$. 
Oraegbunam: Humanism ans the Law: Towards African Rennaissance

In Patristric times, however, "the two streams of humanism came together as they flowed into Judeo-Christian waters" Accordingly, "the chief message of Torah was to do the will of God and a condition for that was to practice social justice" ${ }^{\text {"6. In }}$ the medieval synthesis, "the Greco-Roman paideia and philanthropy were seen as praeparatio evangelica for the law and the prophets which had been fulfilled in Jesus" "7. Love of God and neighbour has become the fulfillment of the law. The new philanthropy wins over the new paideia. In Scholastic era, "humanisim was interpreted as the cultivation of the liberal arts" . Thus, paideia as trivium and quadrivium grew in influence and prepared the way for all students of medicine, law, philosophy and theology.

But "it was Renaissance humanism that became the paradigm for all time of paideic humanism" ". The flow of free inquiry which began with the Sophist was institutionalized in Roman education, and became the university movement in the thirteenth century which broke forth in a flood of creativity. It permeated not only into philosophy, theology, medicine and law but also into every recess of the entire culture ${ }^{10}$. However, a resuscitation of philanthropic humanism was made in the period of enlightenment. It was the spirit of the latter that gave birth to "the French and American Revolution ever since...".11. By working within the limits of reason alone, enlightenment man wants to make this earth a better place. It is out of this enlightenment spirit that Marxism, existentialism and eupraxophy as humanisms flow. Goicoechea has thus made an outline of the history of humanism in relation to paideia and philanthropy. Hardly however had he made any attempt to make explicit pronouncements on how humanistic spirit can alleviate the problems of the subjugated peoples of the different times.

Important submissions were however made by Goiecoechea in another article Zarathustra and Enlightenment 
Ogirisi: a new journal of African studies vol 92012

Humanism. In this, an assessment of enlightenment humanism in the light of Fredrick Nietzsche's work Thus Spoke Zarathustra is made. Reviewing Nietzsche work, he writes that:

Its drama is that of spirit becoming camel and then lion and finally child. The camel is the symbol of Christian Platonism; the lion is the symbol of enlightenment humanism. The child is the symbol of post - modern Dionysianism ${ }^{12}$.

Goiecochea observes that the drama of Zarathustra is primarily that of conflict of love as practised by the camel, the lion and the child:

The camel has the fundamental attitude which orders life around love of God and love of neighbor. The lion has acquired a new fundamental attitude... The enlightenment humanist seeks to love all men and secure for them justice and peace upon earth. The fundamental attitude of the child will be a new love, the love of eternal recurrence ${ }^{13}$.

In the final analysis, this interpretation maintains that the metaphysics of rugged individualism or autonomy of the lion (enlightenment humanism) is overcome throughout the text of Zarathustra. The metaphysics of the child stresses unity of life with nature and all men. It is concluded that "the cold solitude of enlightenment metaphysics is as false as the limited calculus of its epistemelogy" 14 . The child is aware of his dependence. He does not live in the illusion of autonomy. The child's metaphysics sees the one within the many rather than each isolated individual. In this account therefore, the impression left by Zarathustra and Goiecochia is of humanism that is both communal and non-individualistic. But considering 
Oraegbunam: Humanism ans the Law: Towards African Rennaissance other work written by Nietzsche, one can hardly told that this humanism is theistic.

In our times, Martin Heidegger's Letter on Humanism proves to be one of the most significant publications on the question of humanism in its varieties, challenges, and enigmas. Heidegger challenges humanism from the perspective of the proper dignity of man within the ontological framework. In his thinking as thanking and not as calculating, he argues that each western humanism is either grounded in metaphysics or is the ground of a metaphysics:

Every humanism is either grounded in metaphysics or is itself made to be the ground of one. Every determination of the essence of man that already presupposes an interpretation of man without asking the truth of Being whether knowingly or not is metaphysical. The result is that what is peculiar to all metaphysics specifically with respect to the way the essence of man is determined is that it is humanistic: Accordingly every humanism becomes metaphysical ${ }^{15}$.

But according to Heidegger, metaphysical humanism, despite its good intentions, actually forsakes man and the humanitas in homo when it believes that it can adequately define man's essence in terms of animalitas. Thus all humanisms in the opinion of Heidegger are tied to the assumption that man is the rational animal. This constitutes for him the metaphysical limitation of Roman, Renaissance, Enlightenment, Marxist, existentialist, Christian humanisms. Heidegger concludes that the human will receive its proper dignity only through that thinking which is properly thankful for the gift of Being. Humanisms are forgetful of Being and therefore not properly grateful. For man to live in his highest dignity, it is not enough for him to think of himself as a 
Ogirisi: a new journal of African studies vol 92012 rational animal as all the humanisms do. For Heidegger, homo begins to become humanism when he let himself be reclaimed and governed by Being.

To think the truth of Being at the same time means to think the humanity of homo humanus: What counts is humanitas in the service of the truth of Being but without humanism in the metaphysical sense $^{16 .}$

From the above considerations, one discovers that Heidegger's discourse on humanism is intrinsically connected with his critique of traditional metaphysics and the quest for Being which according to him is "the basic question of philosophy" ", a task he has taken upon himself and refers to it as "that of unfolding the truth of Being"18. But it remains to state in the words of Richard Brown whether Heidegger's real humanism is not "riddled with the kinds of vagueness and arbitrariness which could easily precipitate into inhumanism"19. Should we still keep the name humanism for a humanism that contradicts previous humanism? The burden of proof still lies on Heidegger.

Jean Paul Sartre, on the other hand, views humanism as existentialism. His view on humanism is contained in a 1945 lecture entitled Existentialism Is a Humanism ${ }^{20}$. The question to which Sartre addressed himself was how to bring the spontaneity of human consciousness to being so that it answers to, becomes responsible to, the real need of men and women in this world, rather than the dubious condition of personal salvation beyond it. Therefore, the aim of Sartre's atheistic humanism was to reabsorb the meaning of good and evil, virtue and vice into the person and into the community, rather than father them as a transcendent sphere. Sartre's humanism differs from that of Heidegger. While Heidegger wants to show how human being in its most general phenomenological 
Oraegbunam: Humanism ans the Law: Towards African Rennaissance description as being-in-the world is an expression or mouthpiece of Being itself, Sartre wants to show how each unique individual makes his own life in conjunction with other unique individuals. At this juncture however, one may not overlook the fact that Sartre's humanism is not an integral one.

It is this partial individualistic and relativistic humanism of Sartre that provoked Calvin Hayes. Thus in a paper entitled Existentialism, Humanism, and Positivism, Hayes accuses Sartre of ethical relativism based on the latter's thesis that "we can freely invent our values and not discover them or receive them as either divinely revealed or natural objects" 21 . It is really the onus of Sartre to prove within the holistic picture of man whether "existence precedes essence" or vice versa.

McLaughlin in an article Christianity, Humanism, and St. Thomas investigates the relationship between humanism and religion. "Ought the religious person to be a humanist and ought the humanist to be religious?"22. He concludes that:

The celebrated humanists of the fifteenth and sixteenth centuries, even when they were reacting against abuse in the Catholic Church were not rejecting religion any more than their heroes from antiquity were atheistic ${ }^{23}$.

Hence, McLaughlin holds that being fully human it requires us to be religious. It is to buttress this fact that Hewith wrote the paper, The Humanistic Implications of Liberation Theology: Juan Luis Segundo and Karl Marx. He writes:

The socialist humanist principle that a human being only realizes one's universal activity as a social being is not antithetical to much contemporary theology (including Liberation theology) which sees the locus of one's encounter with God in one's openness to others in mutual service within the people of $\operatorname{God}^{24}$. 
Tawney in a celebrated work, Equality also notes this point: Humanism is not ... the special mark of a generation which has lost its sense of the supernatural and is groping for a substitute. For in order to be at home in this world, it is not sufficient, unfortunately, to disbelieve in another ${ }^{25}$.

Therefore, one could add that in order to enhance man's well being in this earth, it is not necessary, either, to deny the existence of God.

But Lamont, a veritable representative of the Western atheistic tradition, in his popular work. The Philosophy of Humanism claims to explain "exactly why educated and discerning people turn away from belief in the supernatural and promises to offer specific program leading to a productive, rewarding life that needs no ... faith in an eternal after-life". He writes:

Humanism is the viewpoint that men have but one life to lead and should make the most of it in terms of creative work and happiness; that human happiness is its own justification and requires no sanction or support from supernatural sources; that in any case the supernatural, usually conceived of in the form of heavenly goods or immortal heavens, does not exist; and that human beings, using their own intelligence and cooperating liberally with one another, can build an enduring citadel of peace and beauty upon the earth ${ }^{26}$.

Thus, Lamont's philosophy of development is man centered and atheistic. This is contrary to Henri de Lubac's conviction contained in his seminal work, The Drama of Atheist Humanism. "Man cannot organize the world for himself 
Oraegbunam: Humanism ans the Law: Towards African Rennaissance without God; without God he can only organize the world against man. Exclusive humanism is inhuman humanism"27.

Lubac maintains that man is a theotropic being in whom faith is indestructible in his heart though violently attacked on all sides. He would hold with Dostoevsky that "if God is nothing, everything is permitted and everything is a matter of indifference",28.

It is against the background of the attempt to expel God from human affairs so that everything would be permitted that Jacques Maritain would refer to Godless and anthropocentric humanism as a tragedy. Hence in his work Integral Humanism, Maritain devotes the first chapter to his disapproval of the classical humanism and eventually comes out with the thesis that even without knowing it, "Western humanism has religious and transcendent source without which it is incomprehensible to itself", 29 .

We cannot conclude this review without making reference to an important work, The New Humanism, published by one of the Nigerian philosophers, Udo Etuk. The new humanism which Etuk proposes shifts man from being the center and measure of all things; from being his own God, to a new conception where man's dignity derives from being created in the image of God.

Man's dignity is not sui generis, man's dignity does not derive from man, nor can confer inestimable value on another man....; dignity of man is conferred on man by the one who created man in his own image, and that to discount this factor is, in fact, to de-value man ${ }^{30 .}$ 
Ogirisi: a new journal of African studies vol 92012 It however remains for Etuk to state what is really new in this humanism where this is exactly the point that was orchestrated by Maritain and de Lubac very much earlier before him.

\section{Humanism in African Thought}

In a cultural environment that relies much on oral traditions and expressions, there is always a noticeable lack of documentations. Thus, in terms of works which titles appear under the name, African Humanism, the above assertion is true in the case of black Africa as a whole.

However, at the end of his last book, The Wretched of the Earth ${ }^{31}$, Frantz Fanon projects the emergence of a new man against the background of the inhumanity of the past occasioned by racism, slavery and Western colonialism. Therefore, Fanon's project of new humanism is a reaction to the fact that the colonial powers and colonizers did not accord full humanity to the colonized. This is a following-up to Hegelian and Levy-Bruhl anthropologies that regarded Africans as pre-logical and consequently not fully human. Fanon thus demanded nothing short of freedom and authentic universal humanism. He however took the violent and confrontational stance of Marxist dialectical framework.

In response to Fanon's humanism, Onwuanibe has dedicated a whole book which he entitled A Crtique of Revolutionary Humanism: Frantz, Fanon. Onwuanibe seems to offer a justification for Fanon's revolutionary violence. He writes:

I think that the resolution hinges on considering decolonization or the liberation movement on the principle of self-defense in which revolutionary violence is a means. The justifiability of violence on the principle of self-defense reinforced by the principle of double-effect shows that violence can be reconciled with humanism. On this ground, I 
Oraegbunam: Humanism ans the Law: Towards African Rennaissance think that Fanon's humanism can be reconciled with this espousal of violence ${ }^{32}$.

However that may be, Onwuanibe does not fail to delineate the theistic signification of African humanism.

It is important to note here that the authentic humanism that will form the atmosphere for the growth of Africa must take into account the spiritual and religious transcendence in African culture: atheistic humanism falls short of the real expectations of African ${ }^{33 .}$

Again, in a seminal article entitled African Humanism: A Cultural Factor in the Development of the Nigerian Personality, Ikenga-Metuh writing of the multi-faceted nature of African Humanism notes that "African Humanism is an outlook and an attitude to life which extends to every aspect of life-the social, religious, political and ethnical life"34. This is to say that any discussion on integral African man must include reference to all these dimensions of human life. It is important to note that in all forms of African life, man occupies the central position. Hence, it is observed that "man is at the center in the hierarchy of being in African worldviews, so that he benefits from the influence of the beings above him and those below him ....Man maintains a vital relationship with God, the deities, ancestors, the tribe, clan and with nature as a whole ${ }^{35}$. Ikenga-Metuh discusses the anthropocentric nature of African Humanism in a more detailed form in another book of his, God and Man in African Religion ${ }^{36 .}$ Mbiti corroborates this view of the centrality of man when he observes that "African ontology is vertically anthropocentric: man is at the very center of existence and African peoples see everything else in relation to this central position of man...."37 Similarly, Iroegbu devotes a reflection on the relationship between the cosmos and the 
Ogirisi: a new journal of African studies vol 92012 human being. He writes of the African man as existing on relatedness with the other: "The category of Being-with is now popular in describing that fundamental relatedness that makes the person a person in African thought. It ends to all facets of life",38.

This seems to implicate the idea of communalism. Nze, nonetheless, sees more in this communalism. He regards it as being in accord with human dignity and hence genuine humanism. Nze sees communalism as that "socio-political order of life that accords with human dignity, that accommodates all men, that gives equal rights to all men because it is natural to them" "39. The present writer thinks that African development to be really authentic must be pursued along this line. Kaunda who prefers to be called a humanist has equally in two works of his: A Humanist in Africa ${ }^{40}$ and Zambia Humanism ${ }^{41}$ emphasized the centrality of man in every ideology. He believes that human personality should have an intrinsic value of its own and the needs of every person are a criteria to measure progress. Therefore, Kaunda is an advocate for the well-being and dignity of the human person. Such works popularly regarded in contemporary African philosophical parlance as nationalist ideological, though mere reactions to colonialism and lack serious philosophical underpinnings, nevertheless share the views of Kaunda. They include Nyerere's Ujamma, Senghor's Negritude, Azikiwe's Neo-welfarism, etc. Included in the list, though of more philosophical rigour, are the works of Nkrumah who was a trained philosopher: Consciencism, Neocolonialism: The Last Stage of Imperialism, African Must Unite, and so on.

Be that as it may, Uwalaka's views in this respect are very spectacular. Uwalaka maintains that "man in his integrality should not be sacrificed at the altar of certain economism, ideology, or certain mechanical or anonymous 
Oraegbunam: Humanism ans the Law: Towards African Rennaissance processes"42. This inclusive humanism must be the model for African development, and for him this "humanism is compatible or even defended by theism"43. This is also the subject of Dukor's Theistic Humanism: Philosophy of Scientific Africanism ${ }^{44}$

\section{Towards Integral Humanism}

A critical consideration of the above views on western and African humanism will not fail to reveal the high extent of variation in the understanding of the term "humanism". Madigan says that "to speak of humanism at all, one must recognize its evolutionary character" 45 . Some forms are either ethical or liberal; others are either collectivist or existentialist. Others still are either deistic or atheistic. Some forms however are recognized as theistic. But be that as it may, Kurtz holds that western humanism includes at least four main characteristics.

(1). It is a method of enquiry; (2) It presents a cosmic worldview; (3) It contains a concrete set of ethical recommendations for the individuals life stance; and (4) It expresses a number of social and political ideas 46 .

It is against this back drop that we make our critique of popular humanism upon which western understanding of development is built.

\section{A Method of Inquiry}

Kurtz writes that the "first principle of humanism is a commitment to free enquiry in every field of human endeavour" "47. This perhaps explains why a fundamental option was made in favour of reason and science. Madigan suggests that Renaissance humanists like Petrarch, Erasmus, and Pico Della Mirandola "did not seek to abolish Christianity, and in fact considered themselves to be good sons of the church. But they did seek to abolish the church's impediments to free 
Ogirisi: a new journal of African studies vol 92012 enquiry and its control over learning,"48. Humanist epistemology rejects the use of authority other than that of science and reason. It is this avowal of the primacy of human reason that inevitably led many enlightenment humanists to become deists, believers in a God of reason, and other humanists like Sartre, to profess atheism.

But at this juncture, it is worthwhile to ponder over these questions: Is science everything, or is there something non-science which is yet important for the full attainment and realization of the human dignity which is the concern of all humanists? Has science found the solution to all of human problems and difficulties? What are the precedents that should encourage man to pin his entire fault on science? Is it possible to see even in science the handwork of the supernatural, or are all the eminent scientists who are also theists and supernaturalists groveling in their superstitions? To what extent can human reason go? ${ }^{49}$.

A dispassionate tackling of these questions will unfold the limitations of science. Its method is restricted to physical phenomena, and it would be reductionism to hold that our conception of reality is exhausted by physical phenomena. It is this empirical reductionism that led Kant to conclude that human knowability stops with the phenomena. But how does the scientific method apply to a wide range of human emotions and experiences, such as religious feeling, falling in love, and so on. It must also be realized that there are grave issues in the world which science and reason cannot deal with. The problem of world peace, for instance, is a problem beyond the powers of science to handle. Thus, science may invent nuclear weaponry but it has not yet succeeded in finding a solution to the problem of wars and conflicts.

If then the method of science is adequate for a fuller study and understanding of man, would it not be foolish for the preponderant atheistic or deistic stance of western humanism 
Oraegbunam: Humanism ans the Law: Towards African Rennaissance to reject other methods and means such as religion which have contributed immensely to our understanding of reality. Yet western humanist is wallowing in the megalomania which regards man's reason and intellect as boundless. It is our submission that because most of Euro- American humanism sees science not as a means but as an end in itself, such humanism is not integral humanism. Every form of development that is based on that is not a holistic one. Western humanism may be humanistic in its pursuit of free enquiry but the problem is that it has anchored such pursuit on a partial authority.

\section{A Cosmic and Evolutionary Worldview}

Western humanist does not simply assert a method of inquiry based upon the methods of science; it equally seeks to use the sciences to interpret the cosmos and the place of the human species within it. The evolutionary theory of Charles Darwin was a tool ready to hand. Evolution unlike other theories of origin like creationism and emanationism does not require God or any other creator as the origin of life. Rather, it maintains that life started spontaneously from non-living matter. V.P Alexeev had written his The Origin of the Human Race toeing this line. In relation to humanism, Karl Marx had capitulated this evolutionary, historical, dialectical movement to materialism, a left wing germination of the seed that was sown by Hegel. Thus, the humanism that is engineered by this worldview is skeptical about the entire drama of the theistic universe.

But how factual is the evolutionary view? The problem of the absence or rarity of intermediate forms in the fossils proves to be a permanent thorn in the flesh of this theory. Yet the whole of Hegelian and Marxian systems were built on it. It is our view that the eventual materialism that resulted therefrom is a partial view of the world. Evolutionary worldview thrives on conflicts and survival of the fittest. This 
Ogirisi: a new journal of African studies vol 92012 perhaps accounts for several wars and conflicts in the world today based as it were upon the negative use of science and technology in the manufacture of biological and nuclear weapons of mass destruction. One can therefore argue that much of western humanism is not integral as it is its "survivalof- the- fittest" motto that partly constitutes the bane of the socalled "third world" countries today.

\section{Ethical Life Stance}

Humanism is also concerned with the right conduct of life. This is ethical humanism and it is within this stance that the sophists, Socrates, Aristotle, Marx, and so on, have tried to evolve their respective ethical systems. There are various ethics however. In our study above, apart from Socratic ethics and Kierkegaardian teleologism, most of humanist ethics do not look up to heaven for a promise of divine deliverance.

A panoramic view will reveal the above assertion to be true. The relativist morality of the sophists begins and ends with this world since nothing according to Protogoras can be known about the gods. The eudaemonian ethics of Aristotle is concerned with this-worldly morality as there seems to be no evidence for Aristotle's belief in immortality. The Machievellian ethics is that of "might is right" and the endjustifies- the means. The Kantian categorical imperative is a cosmic ethic since God as an object of metaphysics is consigned among the antinomies. The principles of Hegelian ethics could not have emanated from a personal God but from a God that is in man. This is true as it is only "the real that is rational and the rational real". For Marx and Comte, ethics is restricted to the social realm. This is probably why Corliss Lamont says of morality that it is a "social product". "Moral standards, like the categories of mind, originate and evolve in the course of human association. Hence, morality too is a social product" 
Oraegbunam: Humanism ans the Law: Towards African Rennaissance

The implication is that western humanist ethics in the main is pure naturalism and as such lacks proper moral standard. Being permissive, it allows subjective whims and caprices to prevail. A host of other inadequacies can be pointed out in such a naturalist morality .If morality is a social product, how does the humanist explain the fact that in every society, one finds individuals who rise up and stand out in judgment against the society? Etuk maintains that naturalism will always be at a loss to explain the binding force of the moral law, the insistence of the gnawing conscience, the universal human predicament which induces man whenever left to himself to go wrong, the intractable problem of sin, the joy and peace which come from the restoration of broken relationships and many more things which go into the making of an ethical life? ${ }^{52}$. Naturalistic ethics therefore cannot be a good foundation for development.

\section{Social Polity}

Humanism is also concerned with the achievement of good society. For Plato, justice can best be seen writ large in the state, but it is also seen in the life of the individual soul. Justice involves the principles of harmony, order and reason. For Aristotle, ethics and politics are related. For both, aristocracy is the best form of government for man. For Karl Marx social praxis was essential for humanism. Marx's theories which were grounded in Hegelian categories however seem to have submerged the individual before the dialectical process of history, and the decisive forces on the historical stage were economic and social. However that may be, most western humanists advocate for democracy by which according to Kurtz "an indelible feature of humanism is its emphasis on freedom",53, a freedom which cannot be sacrificed at the altar of the collective. Lamont writes that "humanist principles demand the widest possible extension of democracy to all relevant aspects of human living,"54. 
Ogirisi: a new journal of African studies vol 92012

It goes without saying that most western countries and recently 'third world' countries have long since embraced democracy. But its inherent inadequacies still remain despite its popularity. The tyranny of the majority over the minority, and lengthy time taken before any governmental execution, to say the least, remain negative indices or liabilities in the practice of democracy. But it seems it is the lesser evil upon which human development can be based.

\section{Need for Humanistic Legal Regime}

It has often been said that law is an ass. What this probably means is that law is Janus-faced capable of setting things right or putting things in disarray. Accordingly, law is a doubleedged sword. However, they bad consequence of the use of law is an unfortunate human phenomenon. In spite of the myriad theories or schools of law, law is essentially an instrument of social ordering or engineering, to use the terms of Roscoe Pound. It is geared towards human development. After chiseling out the excesses of each theory of law, the collection of the respective residues would constitute an instrument of human progress which is the quintessence of any genuine humanism. Hence, natural law theory in its various strands emphasizes the universal and objective principle of morality, equity, fairness and justice. While that is appreciable, the non-enforceability of the legal regime surely constitutes a demand for the development of positivism.

Austinian positivism stresses the particularity and the relative nature of law, and hence suggests that law properly socalled is a command from a political superior to an inferior and backed up by sanction. Again, Kelsen's positivism enunciates a pure theory of law precipitating unto an unfortunately unidentifiable grundnorm. With its principle of efficacy and affectivity, Kelsen's view absconds from the materiality of the content of a particular law. Thus, it settles with the philosophy of "once it is efficient and effective, then it passes the test of 
Oraegbunam: Humanism ans the Law: Towards African Rennaissance legality". Perhaps, what is pretty about positivism is the emphasis on the need to enforce the law and step it down to the needs of particular society or jurisdiction. It is this societal and spatio-temporal context of the nature of law that positivism shares with its daughter-schools such as the sociological, the functional and the historical theories of law.

In its own turn, the economic theory following the inspiration of Marxism underscores that for any piece of legislation to qualify as law, that piece must be geared towards economic upturn. Marxism has put every social institution (education, religion, society, politics, law, etc.) on the foundation of economy as substructure. Marxist economism is therefore a system that rises or falls with its many parts. However, after a possible surgery for a radical excision of its malignant organs and jettisoning them into the oceanic abyss, one would arrive at a safe Eldorado of the urgency and the importance of genuine economic development that is essential to human progress.

Genuine law and legislation thus constitutes a recipe for human development. Legislations and legal regimes must be made to respond positively to the demands of integral human development. As a very dynamic tool for societal arrangement and organization, legislations must avoid the pitfalls of different strands of humanism, western or African. Law making must sort out the various needs of the African peoples in their particular jurisdictions and respond to those needs. Law making must respond to the problems of Africa which as at the moment is constituted by lack of genuine freedom, want of social security, economic strangulation and poverty, maladministration, bad followership, autochthonous imperialism, corruption in high and low places, electioneering malpractices, and sundry ills. Hence, to arrive at genuine development of the African person, the institutions of law making, law enforcement and law interpretation must be 
Ogirisi: a new journal of African studies vol 92012 strengthened. Development and genuine interests of the African human persons must be uppermost in the minds of the African political leaders. Selfish interest and egotism must give way to the spirit of service and sacrifice that are necessary ingredients for human progress,

\section{Conclusion}

This paper had made a critical review of the philosophical motions and interpretation of humanism in Western and African thought. The reviews discovered that there are competing and even conflicting views on the nature and implications of the concept of humanism. What however is clear is that every genuine humanism must target the integral development of the total person. While many other institutions are germane to the achievement of this aim, the role of law is quite indispensable. But such a legal framework must be one that responds to the genuine needs of the people. In many African jurisdictions bedeviled, as it were, with mosaic of ills, law in its making and enforcement and as an instrument of social engineering is a veritable tool that would help turn around and transform the face of development indices in view of better humane living.

*Ikenga K.E. Oraegbunam, $\mathrm{PhD}$ (Laws), PhD (Rel. \& Soc.) is a Lecturer, Dept of International Law \& Jurisprudence, Faculty of Law, Nnamdi Azikiwe University, Awka. 
Oraegbunam: Humanism ans the Law: Towards African Rennaissance

\section{References}

1. Olayinka Opafola, The Role of Philosophy in Human and Political Development in

Ayo Fadahunsi (Ed), Op. Cit., p.9.

2. P. Iroegbu, Enwisdomization and African Philosophy (Owerri: International University

Press, 1994), p.81.

3.David Goicoechea, Preface in David Goicoechea et al (eds), The Question of

Humanism: Challenges and Possibilities (New York: Prometheus Books, 1991), p.8.

4.Ibid., p.9.

5.Ibid.

6.Ibid.

7.Ibid.

8.Ibid.

9.Ibid.

10.Ibid.

11.Ibid., p.10.

12.David Goicoechea, Zarathustra and Enlightenment Humanism in David Goicoechea et al (eds.), Op. Cit., p.170.

13.Ibid., p.171.

14.Ibid., p.177.

15.Martin Heidegger, Letter on Humanism in Basic Writings, trans. David Farrell Krell (New York: 1977), p. 202.

16.Ibid., p. 231.

17.Martin Heidegger, Kant and the Problem of Metaphysics, transl. J.S. Churchill

(Bloomington: Indiana University Press, 1963), p.255.

18.Martin Heidegger, Introduction to Metaphysics, trans. R. Mannhein (New York:

Doubleday, 1961), p. 81.

19.Richard Brown, Heidegger: What is Called Humanism in Goicoechea et al (eds.), $O p$.

Cit., p. 187.

20.J.P. Sartre, Existentialism is a Humanism in Walter Kaufmann, Existentialism from

Dostoevsky to Sartre (Magnolia:Mass., 1984), p. 353.

21Calvin Hayes, Existentialism, Humanism, and Positivism in Goicoechea et al (eds.),

Op. Cit., p. 106. 
Ogirisi: a new journal of African studies vol 92012

22.R.J. Mclaughlin, Christianity, Humanism, and St. Thomas in Goicoechea

et al (eds.), Op. Cit., p.70.

23.Ibid.

24.Marsha Hewith, The Humanist Implications of Liberation Theology:

Juan Luis Segundo and Karl Marx in Goicoechea et al (eds.), Op. Cit., p. 255.

25.R.H. Tawney, Equality (London: Unwin Books, 1964), p.85.

26.Corliss Lamont, The Philosophy of Humanism (New York: Fredrick Unger, 1979), p.12.

27.Henri de Lubac, The Drama of Atheist Humanism (New York: Sheed and Ward, 1950), p.ix.

28.Ibid., p. 212.

29.Jacques Maritain, Integral Humanism (New York: Charles Scribner's Sons, 1968), p.4.

30.Udo Etuk, The New Humanism (Uyo:Afahaide and Bros Printing and Publ. Co.,

1999), p.3.

31.Frantz Fanon, The Wretched of the Earth. trans. Constance Farrington (New York:

Grove Press, Inc. 1967)

32.Richard Onwuanibe, A Critique of Revolutionary Humanism: Frantz Fanon

(Missouri: Warren H. Green, Inc, 1983), p.79.

33.Ibid., p.16.

34.Emefie Ikenga-Metuh, African Humanism: A Cultural Factor in the Development of

Nigerian Personality in E. Ikenga-Metuh and Olowo Ojoade (eds.), Nigerian Cultural

Heritage (Onitsha:Imico Publ. Comp; 1990), p.164.

35.Ibid., p.169.

36.Emefie Ikenga-Metuh, God and Man in African Religion (Enugu:Snaap Press Ltd, 1999), pp.113-120.

37.John S. Mbiti, African Religions and Philosophy (London: Heinemann 1977), p.92.

38.Pantaleon Iroegbu, Metaphysics, the Kpim of Philosophy (Owerri: International

Universities Press Ltd., 1995), p.79.

39.C.B. Nze, Aspects of African Communalism (Onitsha: Veritas Publishers, 1989), Preface. 
Oraegbunam: Humanism ans the Law: Towards African Rennaissance 40.Kenneth D. Kaunda, A Humanist in African, Letter to Collin M.Morris, (Great Britain:

1967), pp. 28-29.

41.Kenneth D. Kaunda, Una Zambia Zambiana (Rome: 1971), pp.28-29.

42.Jude Uwalaka, Inclusive Humanism: The Basis of a Sound Sociopolitical Order for

Africa in Obi Oguejiofor (ed.), Africa: Philosophy and Public Affairs (Enugu : Delta

Publications LTD., 1998), p.94.

43.Ibid.

44.Maduabuchi Dukor, Theistic Humanism: Philosophy of Scientific Africanism

(Lagos:Chimah and Sons Production,1994), pp. 9-18.

45.Tim Madigan, Tim Madigan, Afterword:The Answer of Humanism in David Goicoechea, John Liuk and Tim Madigan (eds), The Question of Humanism: Challenges and Possibilities (New York :Prometheus Books, 1991), p.237.

46.Paul Kurtz, Secular Humanism and Eupraxophy in Goicoechea et al , Op.Cit_, p.308.

47. Ibid.

48.Tim Madigan, Art.Cit., p.328 .

49.Udo Etuk, Op.Cit., p.78 .

50.V.P.Alexeev, The Origin of the Human Race (Moscow: Progress Publishers, 1986), title page.

51. Corliss Lamont, Op.Cit., p.89.

52.Udo Etuk, Op.Cit., pp.70-71.

53.Paul Kurtz, Art. Cit., p.322.

54.Corliss Lamont, Op.Cit., p.261 . 